\title{
KONSERVASI TRADISIONAL BERDASARKAN NASKAH KUNA DI BALI
}

\author{
Isni Wahyuningsih, Henny Kusumawati, S.S., Sri Sularsih S.H. \\ Iwan Kurnianto S.T., Siti Yuanisa, A.Md
}

\begin{abstract}
Abstrak : Naskah-naskah kuna masih banyak dijumpai, dihormati dan dilestarikan di Bali. Naskah-naskah kuna tersebut dimiliki oleh pemerintah maupun oleh masyarakat Bali. Naskah-naskah tersebut dikelompokkan dalam 15 jenis yaitu babad, geguritan, kanda, kalpasastra, kakawin, kidung, nitisastra, mantrastawa, palakerta, parwa, sasana, tantric, tutur, usada, dan wariga. Dari beberapa jenis naskah tersebut naskah tutur dan usada ditengarai terdapat unsur yang mengandung informasi praktek-praktek konservasi. Kajian Konservasi Tradisional Berdasarkan Naskah Kuno di Bali ini bertujuan untuk mendapatkan pengetahuan tentang praktek-praktek konservasi yang dimuat dalam naskah kuna yang hingga sekarang masih dilakukan masyarakat Bali. Langkah-langkah yang dilakukan dalam kajian ini adalah telaah kepustakaan dengan mengambil sampel naskah yang sudah diterjemahkan, mengkaji lembaran naskah yang kemungkinan mengandung muatan konservasi tradisional, wawancara dengan narasumber dan tokoh masyarakat serta mengamati kegiatan konservasi yang masih dilakukan masyarakat pada saat ini. Harapan dari kajian ini adalah mendapatkan apresiasi tentang kegiatan konservasi yang ditulis dalam naskah kuna, yang dapat menjadi bahan alternatif konservasi tradisional untuk pelestarian cagar budaya.
\end{abstract}

Kata kunci : konservasi tradisonal, naskah kuna, Bali, alternatif, pelestarian cagar budaya.

\begin{abstract}
Ancient manuscripts are still present, being respected, and conserved in Bali. These texts are owned either by the local government or the community. They can be categorized into 15 types, which are, babad, geguritan, kanda, kalpasastra, kakawin, kidung, nitisastra, mantrastawa, palakerta, parwa, sasana, tantric, tutur, usada, dan wariga. From those categories, tutur and usada are presumed to contain information about conservation practices. This study aims to gather knowledge about conservation practices as written in ancient manuscripts that are still being enacted by Balinese people. The steps are literary study by taking samples from translated texts, analyzing texts containing traditional knowledge on conservation, interview with locals and respected elders, observation on current communal practices. The objective is to appreciate the conservation practices as written in ancient manuscripts, which would serve as an alternative for cultural heritage preservation using traditional methodology.
\end{abstract}

Keywords : traditional conservation, ancient manuscripts, Bali, alternative, cultural heritage preservation

\subsection{PENDAHULUAN}

\section{Latar Belakang Masalah}

Praktek konservasi tradisional sampai sekarang masih ada di masyarakat, meskipun di era ini berkembang praktekpraktek konservasi modern yang cenderung menggunakan bahan kimiawi. Konservasi tradisional dapat kita ketahui secara lisan, turun temurun (folklore) maupun tertulis dalam naskah kuna. Naskah kuna merupakan warisan budaya tertulis karya masyarakat di masa lampau yang mencatat informasi tentang berbagai aspek kehidupan. Naskah kuna juga sebagai bukti hasil kegiatan intelektual masyarakat tradisional di masa lampau dalam memecahkan permasalahan dalam kehidupan (local genius) antara lain dalam hal konservasi. 
Indonesia memiliki khazanah warisan budaya tertulis dalam bentuk naskah (manuskrip) yang tersimpan di dalam negeri maupun di luar negeri, milik pemerintah maupun milik pribadi. Di Pulau Bali naskah kuna ditulis pada daun lontar, dan hampir setiap keluarga di Bali mempunyai naskah lontar yang diwariskan turun temurun dan dikeramatkan sebagai bentuk penghormatan.

Upaya konservasi yang dilakukan masyarakat berdasasar naskah kuna menarik untuk dikaji dengan tujuan mendapatkan informasi tentang bahanbahan, peralatan dan metode yang digunakan untuk konservasi. Selanjutnya cara-cara konservasi akan diuji di laboratorium dan hasilnya diharapkan dapat menjadi acuan dalam upaya melestarikan cagar budaya.

\subsection{Perumusan Masalah}

Berdasarkan uraian tersebut di atas rumusan masalah penelitian ini adalah:

Bagaimanakah praktek-praktek konservasi yang ditulis dalam naskah-naskah kuna di Bali?

\subsection{Tujuan Penelitian}

Adapun tujuan dari kajian ini adalah untuk mendapatkan pengetahuan tentang praktekpraktek konservasi berdasarkan naskah kuna yang hingga sekarang masih dilakukan masyarakat di Bali.

\subsection{Manfaat Penelitian}

Manfaat dari kajian ini adalah untuk mendapatkan apresiasi tentang kegiatan konservasi yang ditulis dalam naskah kuna, yang dapat menjadi bahan alternatif konservasi tradisional dalam upaya pelestarian cagar budaya.

\section{TINJAUAN PUSTAKA}

\section{Landasan Teori dan Kajian Terdahulu}

Sunarno mengemukakan bahwa konservasi tradisional adalah tindakan konservasi yang menggunakan bahan dan peralatan tradisional, yang berpatokan pada local wisdom (kearifan lokal) serta pengalaman yang terakumulasi dalam pengetahuan masyarakat setempat atau people knowledge. Praktek konservasi tradisional di dalamnya mengandung unsur bahan dan peralatan tradisional. Bahan tradisional adalah bahan yang diperoleh dari lingkungan setempat atas dasar pengalaman turun temurun. Sementara peralatan tradisional adalah peralatan sederhana yang dibuat masyarakat dengan bahan yang diperoleh dari lingkungannya. Bahan serta peralatan konservasi tersebut yang menjadi pembeda antara konservasi tradisional dan konservasi modern. (Sunarno dalam Swastikawati, 2015)

Upaya penerapan kembali konservasi tradisional dalam pelestarian cagar budaya telah mulai dilakukan, begitu juga upaya untuk mengilmiahkan bahan konservan tradisional tersebut. Salah satunya seperti yang telah dilakukan oleh Swastikawati (2011-2014) yang telah melakukan kajian konservasi cagar budaya berbahan logam menggunakan metode konservasi tradisional dengan bahan-bahan alami. Metode tradisional yang diterapkan dalam kajian tersebut diadopsi dari tradisi lisan yang masih dijumpai dan dilakukan oleh masyarakat sekitar, seperti penjamasan keris dengan menggunakan jeruk nipis. Sementara itu untuk konservasi tradisional yang dirujuk berdasarkan budaya tulis atau teks yang berupa naskah kuno belum pernah dilakukan.

\section{METODE PENELITIAN}

\subsection{Ruang Lingkup Kajian}

Ruang lingkup dari kajian ini adalah naskahnaskah kuna yang tersimpan di Pusat Dokumentasi Lontar di Bali, Gedong Kirtya, BPNB Bali, ANRI dan yang tersimpan dalam masyarakat adat di Bali.

\subsection{Sumber Data}

1. Data primer berupa teks dari naskah kuna yang menuliskan tentang konservasi; dan hasil wawancara dengan narasumber serta tokoh masyarakat yang memahami naskahnaskah kuna.

2. Data sekunder berupa literatur konservasi atau dokumentasi tradisi yang terkait. 


\subsection{Metode Pengumpulan Data}

Pengumpulan data yang dibutuhkan dalam penelitian ini adalah sebagai berikut.

1. Pengamatan dilakukan dengan melakukan penelusuran terhadap naskah-naskah kuna di Bali yang di dalamnya memuat kegiatan atau praktek unsur konservasi tradisional. Untuk mendapatkan data dan lebih memantapkan dalam menelaah naskah-naskah kuna, maka diambil naskah yang sudah diterjemahkan.

2. Wawancara dilakukan kepada narasumber ataupun tokoh masyarakat.

3. Pengumpulan data seku nder dilakukan dengan pengumpulan data literatur dan studi-studi terdahulu terkait dengan penelitian.

\subsection{Metode Analisis}

Penelitian ini menggunakan metode penelitian kualitatif dengan langkah-langkah berikut:

1. Metode telaah kepustakaan. Secara teknis, dalam upaya pengumpulan data dalam kajian ini dilakukan pengumpulan dan pengambilan sampel naskah yang sudah diterjemahkan, wawancara, serta mengkaji lembaran naskah yang kemungkinan mengandung informasi konservasi tradisional.

2. Metode analogi etnografi, yaitu mencatat kegiatan konservasi yang masih dilakukan masyarakat pada saat ini.

3. Pengujian sampel di laboratorium.

4. Kesimpulan.

\section{TINJAUAN KONSERVASI TRADISIONAL PADA NASKAH KUNO}

\subsection{Naskah Kuno di Bali}

Bahan naskah yang digunakan beraneka macamnya yaitu daluwang (kertas jawa); lontar atau lontara (Bali, Lombok, Madura); daun nipah (Sunda, Lombok); kulit kayu
(Sunda, Batak); kertas Eropa; rotan; bambu. Menurut Zoetmulder dalam Kalangwan (1983:154-160;164167) bahan untuk menulis ada:

1. Karas yaitu lembar atau papan untuk ditulisi.

2. Pudak (bunga pohon pandan) daun bunga pandan yang panjang dan putih dipakai sebagai bahan, dan setiap goresan yang dibuat dengan alat runcing pada daun bunga pandan seketika menjadi hitam dan meninggalkan goresan (bahan ini jauh daripada awet)

3. Yasa, Mabanten, Bale

4. Teto, wilah. Teto yaitu papan kayu (pangeret/ blandar) sedangkan wilah yaitu belahanbelahan bambu yang diikat dengan tali (untuk jembatan atap/galar/ kerai) (Zoetmulder,1983:168)

Pencarian data untuk penelitian ini adalah dengan melakukan penelusuran naskah kuno utamanya naskah lontar yang tersimpan di Pusat Dokumentasi Lontar di Bali, Gedong Kirtya, Balai Pelestarian Nilai Sejarah dan Tradisional Bali, ANRI dan yang tersimpan dalam masyarakat adat di Bali. Dalam upaya pengumpulan data dipilih dalam katalog naskah yang sudah diterjemahkan. Untuk mempermudah penelusuran di beberapa tempat tersebut di atas dengan melihat katalog, ataupun database yang diperkirakan dari judul berhubungan dengan kajian. Dalam kajian ini diambil 90 sampel judul naskah, yang sebagian besar merupakan naskah lontar. Naskah lontar di Bali dikelompokkan menjadi 15 jenis meliputi babad, geguritan, kanda, kalpasastra, kakawin, kidung, nitisastra, mantrastawa, palakerta, parwa, sasana, tantri, tutur, usada, dan wariga (Suweda, 1996). Pada kelompok tersebut yang paling dimungkinkan mengandung unsur konservasi adalah kelompok tutur dan usada.

\subsection{Praktek/Kegiatan Konservasi Tradisional} Dalam Naskah Kuna

Kurang lebih 90 naskah kuna diambil sebagai sampel kajian ini. Dari jumlah tersebut, terdapat 3 naskah yang memuat informasi konservasi, berasal dar naskah usada dan tutur. Naskah yang mencatat 
tentang kegiatan konservasi adalah sebagai berikut.

1. Naskah tutur tidak hanya berkaitan dengan masalah keagamaan tetapi juga menyangkut uraian tentang pengetahuan seperti tentang tumbuh-tumbuhan, pengobatan, pertanian dan lainnya.

2. Naskah usada biasanya memuat ciriciri penyakit disertai dengan cara pengobatannya serta obat-obatan yang digunakan. Naskah kuno usada biasanya dimiliki oleh para Balian (ahli pengobatan).

3. Naskah yang dimiliki secara turun temurun pada masyarakat di Bali. Naskah ditulis pada media lontar dan tidak boleh diperlihatkan kepada orang awam, hanya disimpan dibuka pada saat-saat tertentu, dan dengan upacara khusus.

Informasi tentang kegiatan atau praktek konservasi yang ditemukan pada naskah kuna di Bali adalah sebagai berikut.

1. Teks yang memuat mengenai pengolahan daun lontar, diantaranya proses perebusan dengan berbagai rempah-rempah diantaranya pala (Myristica Fragrans), gambir (Disambiguasi), cabe jawa (Piper Refractum Vabl), lada (Piper Albi Linn), kunyit (Curcum Longa Linn), cengkeh (Syzygium Aromaticum) untuk pengawet daun 'tal agar tahan lama. Pemakaian kemiri pada setelah proses penulisan untuk mempertajam tulisan dan untuk mengawetkan lontar itu senidiri. (terdapat naskah lontar yang dimiliki oleh seorang warga di daerah Sidemen, Karangasem,yang turun temurun berprofesi sebagai pengolah lontar)

2. Teks yang memuat penggunaan Lengkuas untuk menghilangkan atau mengobati jamur kulit (terdapat dalam naskah usada milik seorang Balian di Gianyar).

3. Teks yang memuat kegiatan pengusiran serangga dengan cara menebarkan garam, dengan jalan menebarkan pada area tanaman yang diserang serangga.

\section{Pembahasan Terkait Temuan Data Unsur Konservasi Tradisional Berdasarkan Naskah Kuna di Bali}

Pada proses pembuatan atau pemakaian suatu benda akan terbentuk pola tingkah laku atau proses pembentukan budaya (Schiffer, 1976). Pada masyarakat Bali, proses pengolahan daun lontar menjadi media untuk menulis masih berlangsung sampai sekarang. Di daerah Sidemen masih dijumpai pengolahan lontar yang dilakukan dengan proses sebagai berikut.

- Pemetikan dan pemilihan daun lontar dari pohon

- Pemilihan daun lontar yang benar-benar tua dan ukuran yang sesuai

- Penjemuran daun lontar sampai kering di bawah terik matahari

- Pemotongan daun lontar dan melepaskan lidi

- Perendaman daun lontar dalam air tawar selama kurang lebih emapat hari empat malam, air diganti setiap hari.

- Penjemuran daun lontar dan dianginkan kurang lebih tiga hari, dibendel sesuai dengan ukuran

- Perebusan daun lontar dengan berbagai rempah-rempah seperti pala, merica, gambir, kunyit, cengkeh selama satu hari satu malam.

- Pengeringan daun lontar; dan penjepitan/ pengepresan agar lurus selama kurang lebih enam bulan

- Membuat pola dan membagi daun lontar.

- Menyerut daun lontar agar halus dan rapi pinggirannya; mengecat bagian pinggir (biasanya warna merah) .

- Menggarisi daun lontar agar memudahkan dalam proses penulisan.

Agar menghasilkan lembaran lontar yang awet dan dapat digunakan sebagai media menulis, salah satu prosesnya adalah perebusan daun lontar dengan menggunakan rempah-rempah sebagai berikut. 


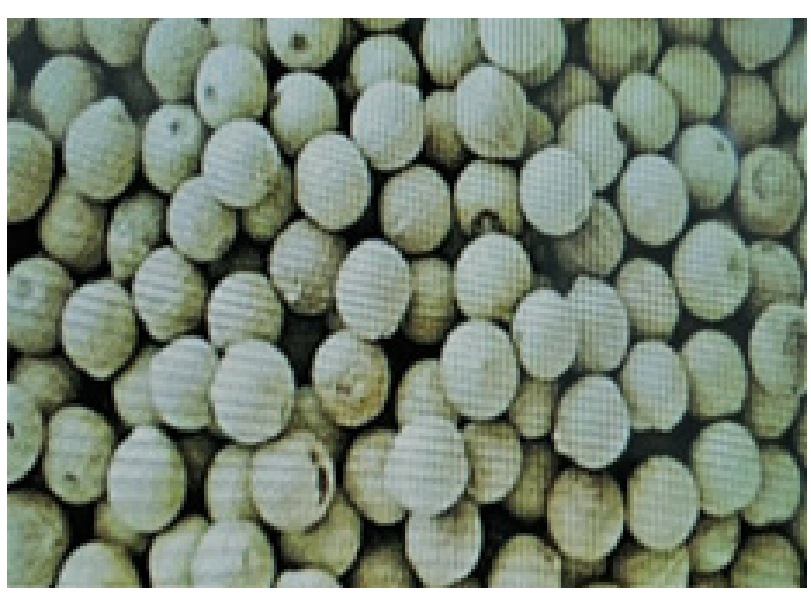

1. Lada (Piper Albi

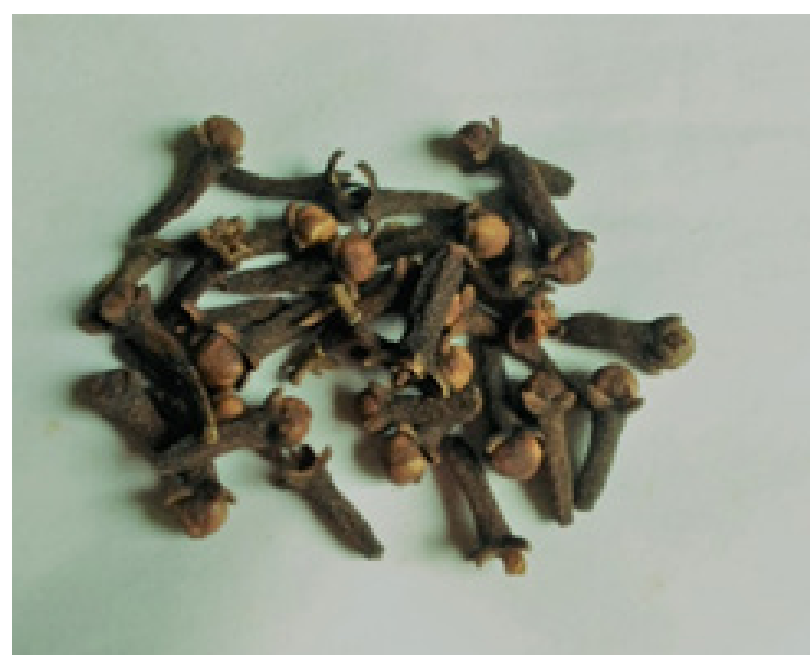

3. Cengkeh (Syzygium

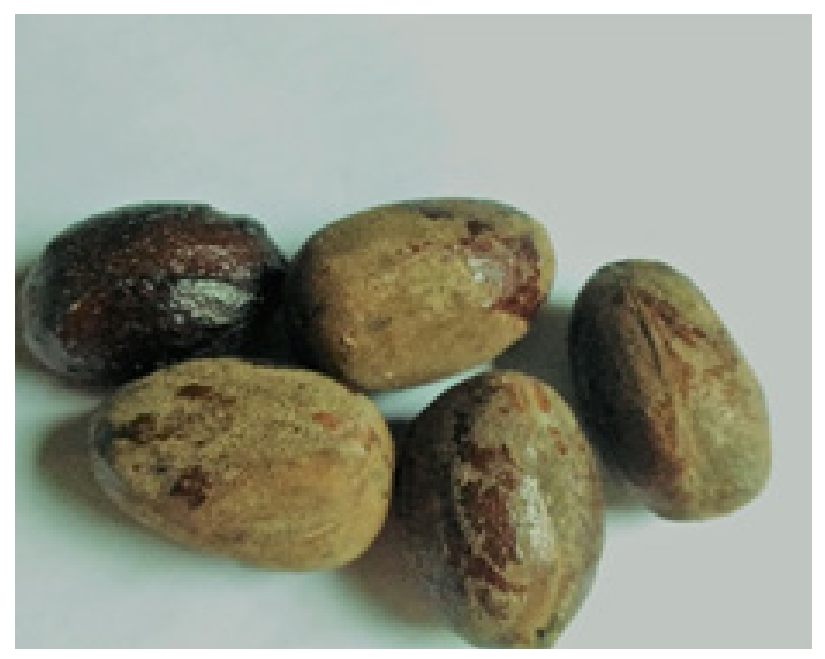

5. Pala (Myristica Fragrans)

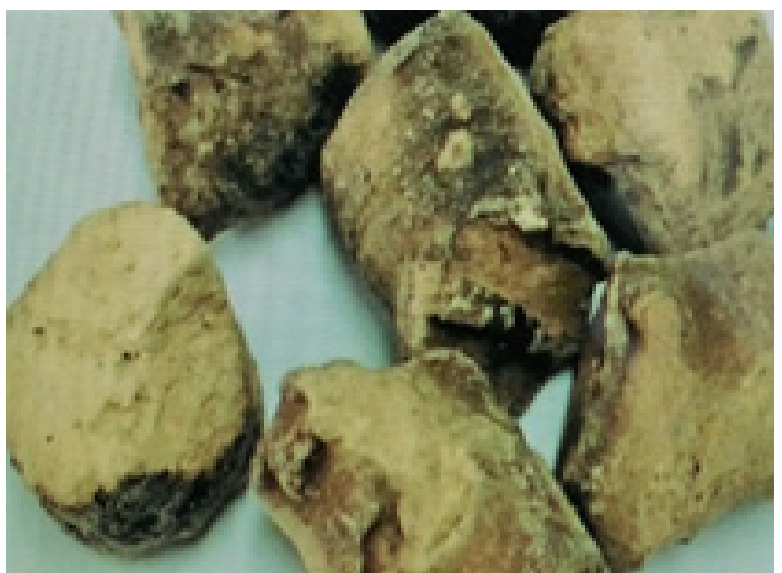

2. Gambir (Disambiguasi)

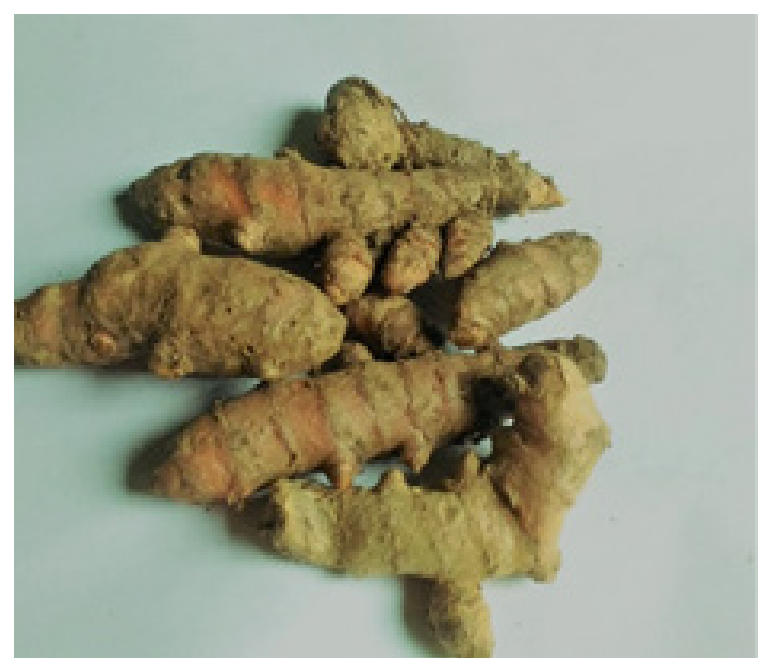

4. Kunyit (Curcuma Longa Linn)

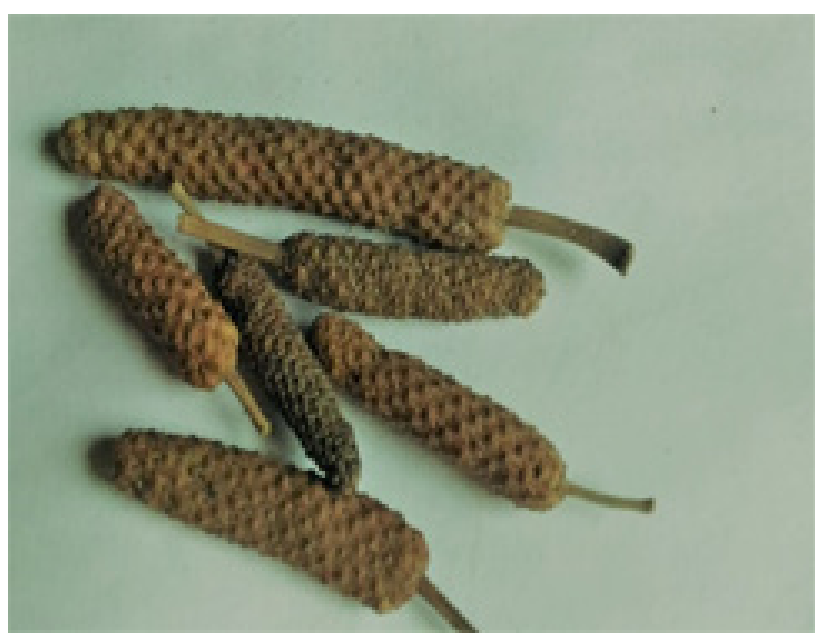

6. Cabe (Piper Retrofractum 
1. Lada (Piper Albi Linn)

Berdasarkan hasil uji laboratorium, kandungan kimia dalam lada adalah saponin, flavonoida, minyak atsiri, kavisin, resin, amilum, piperine, piperiline, piperoleine, poperanine, piperonal, dibdrokarveol, kanyo-fillene oksida, kariptone, tran piocarrol, dan minyak lada.

2. Gambir (Disambiguasi)

Berdasarkan hasi uji laboratorium, kandungan yang utama pada gambir adalah flavonoid (terutama gambirin), katekin, zat penyamak, serta sejumlah alkaloid. Katekin merupakan senyawa fungsional dominan yang terdapat dalam gambir. Ekstrak gambir juga mengandung asam catechu tanat dan quercetine (pewarna kuning)

3. Cengkeh (Sysygium Aromaticum)

Berdasarkan hasil uji laboratorium, cengkeh mengandung minyak asiri, engenol, asetil engenol, kariofilen, furfural, metal-amilketon, vanillin, kariofilen, tannin, gom, serat, air, asam galatanat, kalsium oksalat.

4. Kunyit (Curcuma Longa Linn)

Berdasarkan uji laboratorium, kunyit mengandung minyak atsiri yang terdiri darigolongan,senyawa monoterpen dansesquiterpen (meliputi zingiberen, alfa dan beta-turmerone), zat warna kuning yang disebut kurkuminoid sebanyak 5\% (meliputi kurkumin 50-0\%,monodesmetoksikurkumin dan bidesmetoksikurkumin), protein, fosfor, kalium, besi dan vitamin $\mathrm{C}$.

5. Pala (Myristica Fragrans)

Berdasarkan hasil uji laboratorium, pala mengandung minyak atsiri terutama monoterpena, sinensa, diterpena, pinena, linalool, borneol, terpineol, eugenol, miristin, isoeugenol, dipentena, safrol, minyak lemak, trimiritin terutama berupa gliserida dari asam miristat, asam oleat dan asam linoleat, kadar abu 4\%, pati, dan gula.

6. Cabe (Piper Retrofractum Vabl)

Berdasarkan hasil uji laboratorium, cabe mengandung minyak atsiri 0,6-0,7\%, alkaloid (piperin) dan suatu senyawa amida yang mirip dengan senyawa yang terkandung dalam Piper longumin yaitu piplartin, piplasterin dan sesamin.

Rempah rempah yang digunakan dalam proses perebusan lontar mengandung bahan
Rempah rempah yang digunakan dalam proses perebusan lontar mengandung bahan metabolit sekunder, yang biasa berperan dalam berbagai khasiat (anti jamur, anti serangga). Sementara itu dalam proses penulisan dan pemeliharaan naskah dengan media lontar menggunakan biji buah kemiri.

Naskah ditulis dengan menggunakan pengropak, yang terbuat dari besi berbentuk seperti pisau kecil dengan pegangan terbuat dari kayu.

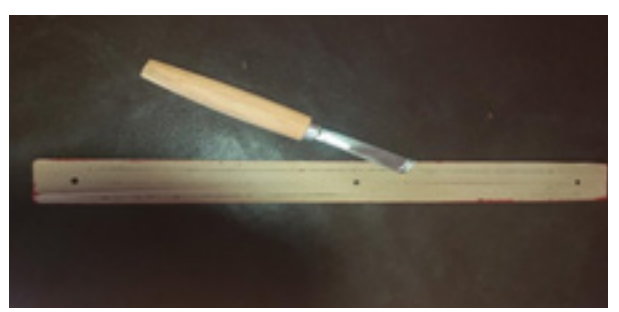

Lontar dan pengropak

(Foto: Wayan)

Setelah goresan huruf selesai dituliskan pada lembaran lontar, kemudian diolesi menggunakan kemiri yang dibakar atau selanjutnya dioleskan secara searah ke lembaran lontar khususnya pada bagian tulisannya.

Kemiri bakar bisa digunakan dalam wujud utuh kemudian dioleskan, ada yang digerus lembut dan dicampur dengan minyak kelapa.

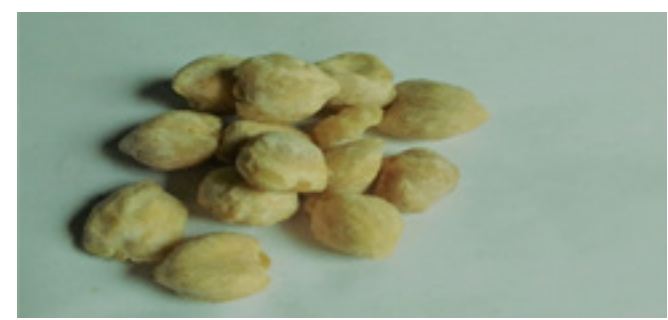

\section{Kemiri (Aleuritus Moluccanus) (Foto: Penulis)}

Berdasarkan uji laboratorium biji kemiri (Aleuritus Moluccanus) mengandung gliserida, asam linoleat, palmitat, stearat, miristat, asam minyak, protein, vitamin B1, dan zat lemak. Manfaat kemiri antara lain terdapat pada minyak kemiri tersebut, yang dihasikan dari tumbukan biji kemiri yang telah disangrai atau dibakar. Benang untuk tenun ikat di Bali Aga juga direndam dalam minyak kemiri selama kurang lebih 6 bulan.

Penggunaan Lengkuas (Alpihia Galanga) untuk menghilangkan atau mengobati penyakit kulit yang disebabkan oleh jamur, dengan cara dioleskan (terdapat dalam naskah usada milik seorang Balian di Gianyar). 


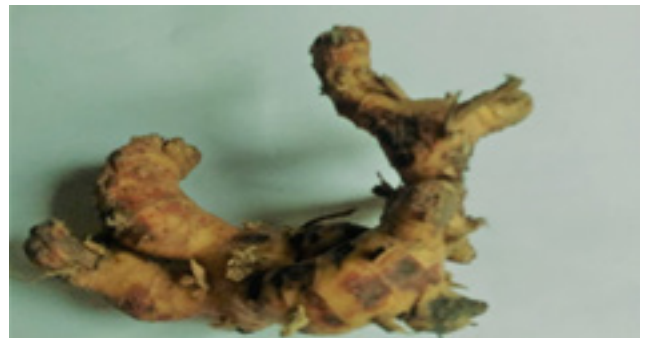

Lengkuas (Alpihia Galanga)

(Foto: Penulis)

Lengkuas (Alpihia Galanga) mengandung caryophyllene oxide, caryophyllene, isorhamnetin, kaemferide, galangin, dan galangin 3, bagian rimpangnya mengandung atsiri, metilsinamat, sineol, kafer, eugenol, galangol, dan juga galangol. Lengkuas berfungsi sebagai anti jamur.

Berdasar uraian di atas, pengetahuan yang telah diturunkan oleh nenek moyang tersebut membuka peluang untuk dapat digunakan sebagai alternatif konservasi tradisional, seperti mengawetkan naskah lontar dan membasmi jamur pada suatu benda cagar budaya.

\section{KESIMPULAN}

Pada naskah-naskah kuna yang tersimpan di Pusat Dokuemntasi Lontar, Gedong Kirtya, BPNB Bali, ANRI, dan yang dimiliki masyarakat adat di Bali terdapat informasi yang memuat praktek atau kegiatan konservasi. Informasi tersebut dijumpai pada naskah usada, naskah tutur dan naskah yang dimiliki oleh masyarakat secara turun temurun.

Praktek-praktek atau kegiatan yang terdapat pada naskahnaskah kuna di Bali adalah sebagai berikut.

Metode perebusan daun lontar dengan bahan rempah-rempah pala (Myristica Fragrans), gambir (Disambiguasi), cabe jawa (Piper Refractum Vahl), lada (Piper Albi Linn), kunyit (Curcum Longa Linn), cengkeh (Syzygium Aromaticum) untuk pengawetan daun 'tal' agar tahan lama. Rempah-rempah tersebut ditengarai mengandung metabolit sekunder, yang berfungsi sebagai anti jamur dan anti serangga. Metode pengolesan searah pada lontar yang sudah ditulisi dengan kemiri bakar. Penggunaan kemiri bakar selain untuk mempertajam tulisan, juga berfungsi sebagai pengawet.

Metode pengolesan pada penyakit kulit yang disebabkan oleh jamur dengan menggunakan lengkuas yang berfungsi sebagai anti jamur.

Metodemenebarkan garam untuk menghilangkan serangga pada tanaman.

\subsection{Saran}

Perlu dilakukan saintifikasi terhadap bahan-bahan konservasi tradisional yang termuat dalam naskah kuna di Bali. Hasil saintifikasi dan uji coba bahan konservan tersebut diharapkan dapat digunakan sebagai bahan alternatif konservasi tradisional pada cagar budaya dengan penerapan yang lebih efektif dan efisien. 


\section{DAFTAR PUSTAKA}

Barried, Siti Baroroh, dkk, 1985. Pengantar Tori Filologi Jakarta: Pusat Pembinaan dan Pengemba Bahasa Departemen Pendidikan dan Kebudayaan.

Dinas Kebudayaan Propinsi Bali, 2016. Biblografi. ali : Dinas Kebudayaan

Mulyana, Deddy, 2001. Metode Penelitian Kualitatif. Bandung : PT. Remaja Rusdakarya.

Suastika, I Made, 1996. "Lontar Proses Pembuatan dan Penyalinannya di Bali" dalam Lontar, Majalah Doukemtasi Budaya Bali edisi No. 1/Triwulan I/1996. Bali : Dokumentasi Budaya Bali.

Sukersa, I Wayan, 2016. “Cara Pembuatan Blangko Lontar dan Kiat-Kiat Merawat Naskah Lontar" dalam Prabhajnana. Bali : Universitas Udayana

Susena, Danang, dkk,2013. "Pengobatan Tradisional Dalam Naskah-naskah Minangkabau dalam Wacana Etnik, Jurnal Ilmu Sosial dan Humaniora Vol. 4 No. 2 Oktober 2013. Hlm 13-152.

Swastikawati, Ari, 2013. Metode Konservasi Tradisional Cagar Budaya Berbahan Logam. Magelang: Balai Konservasi Borobudur.

Tim UPT Perpustakaan Lontar Universitas Udayana, 2013. "Katalog Naskah Lontar". Denpasar : UPT Perpustakaan Lontar Udayana

Universitas Udayana dan UPT Lontar, 2016. Prabhajnana: Kajian Pustaka Lontar Universitas Udayana. Bali : Universitas Udayana

Zoetmulder, P.J, 1983. Kalangwan, Sastra Jawa Kuno Selayang Pandang. Jakarta: Djambatan 